\title{
The Approach of Muhammad Farid Wajdi to the Validity of Prophethood of Muhammad (p.b.u.h) and His Role in Establsihing a Civilized Society
}

\author{
Adibah Abdul Rahim,a,* \\ a Department of Usul al-Din and Comparative Religion, Kulliyyah of Islamic Revealed Knowledge and Human Sciences, \\ International Islamic University Malaysia (IIUM), Jalan Gombak, 53100 Kuala Lumpur. \\ *Corresponding author: adibabar@iium.edu.my
}

\section{Article history}

Received: 2017-10-02

\begin{abstract}
This paper attempts to examine the approach of an Egyptian scholar, Muhammad Farid Wajdi, in his study of Prophet Muhammad (p.b.u.h). Compared to other studies on Prophet Muhammad (p.b.u.h) which are mostly historical and descriptive in nature, the approach of Wajdi is based on a scientific and rational method. Although Wajdi's extensive writings are on various aspects of Prophet Muhammad (p.b.u.h), this paper focuses on his arguments on the validity of the prophethood (nubuwwah) and the revelation and role of the Prophet (p.b.u.h) in establishing a civilized society. The evaluation of the validity of prophethood is necessary to respond to the misrepresentation of Western orientalists of Prophet Muhammad (p.b.u.h) and their rejection of his prophethood. The role of the Prophet (p.b.u.h) in establishing a civilized society is also highlighted to invalidate the claim of the West that the Prophet's role was only confined to the spiritual life of individuals, whilst disregarding the social, political, and economic aspects. Based on his observations and evidences, it can be justifiably claimed that Wajdi was able to refute the misrepresentation of Islam, in general, and Prophet Muhammad (p.b.u.h), in particular.
\end{abstract}

Keywords: Prophet Muhammad (p.b.u.h), Muhammad Farid Wajdi, Prophethood, Revelation, Ummah. 


\subsection{INTRODUCTION}

Wajdi's works on Prophet Muhammad (p.b.u.h) was published in Majallah al-Az̧har within seven years of his writing from 1939 to 1946. Some 80 lectures from different volumes in Majallah alAzhar have been compiled by Muhammad Ragab al-Bayumi in a book entitled, Al Sirah alMubammadiyyah tabta dhau' al 'Ilm wa al-Falsafah, making the reference to the subject easier and systematic. Unlike the other studies on Prophet Muhammad (p.b.u.h) which are mostly historical and descriptive in nature, Wajdi applies a scientific and rational approach. He relates the study of sirah to metaphysical and philosophical issues, such as, what is life, what is the common faith which binds people together and what is the code of morality which they should abide by. The most reliable source for these issues, according to Wajdi, is provided by the life of Prophet Muhammad (p.b.u.h) and his prophetic messages. In relation to Wajdi's discussion on Prophet Muhammad (p.b.u.h), this paper focuses on two aspects: a) the validity of the prophethood (nubuwwah) and revelation (wahy); and b) the role of the Prophet (p.b.u.h) in establishing a civilized society.

\subsection{THE VALIDITY OF PROPHETHOOD AND REVELATION}

In an attempt to prove the validity of the prophethood of Prophet Muhammad (p.b.u.h) and his revelation, Wajdi argues that knowledge of existence could also be sought by other means of thinking of the ordinary human mind. He mentions two means: a) inspiration as a natural common instinct; and b) the extra intellectual gift of human beings (Wajdi, 1993).

In this regard, Wajdi analyses the cyclic life of a female butterfly. He observes that when she reaches the third stage of her life, she puts her eggs on the green leaves of a tree. These eggs will not incubate until the second season of the mother's death. The new-born then eats the leaves. The process is repeated in all generations. Wajdi asks who has taught the butterfly to provide nourishment and how could she know that it is needed during the early stage of life. Was the mother teaching the unborn who she will not see, or is she being guided by her rationality which she does not possess? Wajdi refers to this as an inspiration or a natural animal instinct given by God. This can also be related to the Qur'anic verse: "And thy Lord taught the bee to build its cell in hills, on trees and in man's habitation" (Qur'an 16: 68). These inspirations are the perceptible proof of the knowledge of existence, which is not perceived through the five senses. Wajdi is convinced that if that was possible in animal life, it then is also especially true for human beings who possess stronger consciousness of the spiritual world, thus having a higher potential to accept it (Wajdi, 1993). Therefore, the natural instinct human beings are endowed with could be the means to believe in the truth of the Prophet (p.b.u.h) and the revelations of the Qur'an. Believing in God and the Prophet (p.b.u.h) is considered as human nature. Every man has an inherent inclination towards the belief, and deviation from it is considered as contradictory to human nature. Besides human nature, Wajdi emphasizes on the role of reason in understanding the prophethood and revelation. Accordingly, he argues that there are two elements for the perpetuation of Islam, namely, human nature and its acknowledgement of the role of reason. Wajdi maintains that religion is just a streak of divine nature innate in human souls, provided that this nature remains unimpaired by teachings which force it to change its natural course. This pure and untainted nature which is free from passion, illusion or imitation, is nothing but Islam itself (Wajdi, 1967). 
As for the role of reason, Wajdi says that Islam has established itself as a guideline for all differences in the light of divine revelation. In his attempt to relate human nature to reason, Wajdi argues that man differs in terms of natural instinct and hereditary traits. It is therefore imperative to have an arbitrator to judge. This arbitrator is reason, which is the basis of accountability and the umpire of right and wrong. This combination of human nature and the influence of reason form the basis of religion. By combining these two elements of Islam, i.e., human nature and the role of reason, Wajdi emphasizes that Islam is not merely a religion based on blind imitation; it is in fact a religion based on rational thinking and search for truth. The role of reason helps in dealing with and strengthening Islamic faith (Wajdi, 1967). In a nutshell, the teachings of the Prophet (p.b.u.h) and his revelation are all in accordance with human nature, and none is contradictory to it. They also do not contradict reason or rational thinking. All the religious beliefs, laws and ethical principles are compatible with reason.

As for the second point, Wajdi emphasizes that there is the possibility of an extra intellectual gift among certain groups of people, such as philosophers, mystics and prophets that cannot be experienced by ordinary people. This faculty may allow the possession of a higher source of knowledge, and the ability to gain from it (Wajdi, 1967). In this regard, Wajdi reveals some evidences from these special people gifted with this kind of intelligence as reflected in the work of the English psychologist, Frederic W.H. Myres, in his book entitled Human Personality and the Survival of Bodily Death (Wajdi, 1967). Wajdi's objective here is to prove that the acknowledgement of this noble quality in these special groups of people will open their minds to the possibility of the prophethood of Muhammad (p.b.u.h) and his revelation.

With this profound revelation received by the Prophet (p.b.u.h), and comprehending and conveying it to people, in spite of him being illiterate, the Prophet (p.b.u.h) is endowed with an extraordinary intellectual gift unlike any other. Therefore, Wajdi argues that if we may imagine the miraculous gift of intelligence to certain special groups of people, it is particularly true for the Prophet (p.b.u.h) as well (Wajdi, 1967). However, Wajdi reminds that the prophecy of Muhammad (p.b.u.h) is not necessarily affirmed by the intellectual gift since the Prophet was inspired by revelation. Wajdi does not see intelligence as a means to achieve revelation; it is in fact a gift given by God. He does not deny that effort and acquisition are necessary to prepare the soul to receive revelation, for example, by acts of worship, in-depth thinking and carrying out deeds sincerely. However, prophecy is not attained by pure effort per se. That is the reason why not every philosopher or mystic can become a prophet. In this sense, Wajdi is influenced by alGhazali who believes that prophetic intellectual power is different from ordinary thought (Rahman, Fazlur, 1958).

The other evidence on the validity of the Prophet (p.b.u.h) is the performance of miracles. Since the Prophet's miracles are beyond the ability of human beings and natural phenomena, it is logical for people to acknowledge his prophethood. The Qur'an and Islamic history affirm many miracles, and all these miracles happened, are authentically reported and cannot be denied. Therefore, the accusation made of the Prophet (p.b.u.h) that he is a madman and a magician are totally baseless; his extraordinary acts can be nothing short of miracles. The Prophet (p.b.u.h) performed miracles only when necessary to prove his prophethood; miracles were not performed by him simply for the purpose of entertaining the people.

It is mentioned in the Qur'an that some enemies belittled the miraculous acts of the Prophet (p.b.u.h) and demanded other things as the conditions for the acceptance of faith. The Quraysh asked the Prophet (p.b.u.h) to cause a spring to gush, or to have a garden of date trees, or to 
cause the sky to fall in pieces on them, or to bring Allah and the angels before them face-to-face, or to have the house decorated with gold, or to mount a ladder right to the sky and bring a book which will testify his claim, before they would recognize him as a Prophet. The Qur'an mentioned,

"They say: We shall not believe in thee, until thou cause a spring to gush forth for us from the earth, Or (until) thou have a garden of date trees and vines, and cause rivers to gush forth in their midst, carrying abundant water, Or thou cause the sky to fall in pieces, as thou Sayest (will happen) against us, Or thou bring Allah and the angels before (us) face to face, Or thou have a house adorned with gold, Or thou mount a ladder right into skies. No, we shall not even believe in thy mounting until thou send down to us a book that we could read" (Qur'an 17: 90-93).

In response to those demands, Allah ordered the Prophet (p.b.u.h) to say, "Glorified is my Lord. I am a human being and nothing more. I have been sent from God to you in order to convey His commands" (Qur'an 17: 93). Based on this verse, the Christians rejected the prophethood of Prophet Muhammad (p.b.u.h) because they claimed that in the Qur'an itself, the Prophet (p.b.u.h) was made to disown miracles. Since one of the criteria for prophethood is the performance of miracles, and Prophet Muhammad (p.b.u.h) was never granted that power, and neither did he perform any miracle since the Qur'an asked him to disown it, his prophethood can be rejected on that basis. In this regard, Wajdi refutes this assumption of the Christian intellectuals. The above verse does not prove that the Prophet (p.b.u.h) did not or could not perform miracles. The demands of the Quraysh were not for the Prophet (p.b.u.h) to perform miracles; rather, they were demanded out of ignorance, pride, and obstinacy. It may be observed that their demand that the Prophet (p.b.u.h) should cause the spring to gush forth from the earth is just based on selfish interest, and against the wisdom of God and the creation of mankind. Their demand that the Prophet (p.b.u.h) should create a garden of date palms or to have a house of gold is neither virtuous nor righteous and possibly nothing to do with performing miracles to prove prophethood. The demands cannot be considered as miracles because it is possible for ordinary man to possess such things. Their demand that the Prophet (p.b.u.h) should cause the heaven to fall on them in pieces contradicts the will of God, because causing the heaven to fall in pieces may lead to the destruction of the whole world and God did not create the world to destroy it. Their demand that the Prophet (p.b.u.h) should bring God and the angels before them face-to-face is impossible, and therefore demanding it is illicit or even foolish. If all that they asked for are not miracles, then performing them will never tantamount to miracles. Therefore, using this verse as evidence that the Prophet (p.b.u.h) did not perform miracles is not just misrepresentation but also deviation from academic integrity. Further, nowhere is Prophet Muhammad (p.b.u.h) ordered by God not to perform miracles. The Prophet (p.b.u.h) employed miracles only when absolutely necessary to prove his prophethood; he did not perform them unnecessarily, like for entertaining people. Therefore, the above Qur'anic verse has been misinterpreted by non-Muslims as well as by some misguided Muslim scholars.

The greatest miracle of the Prophet (p.b.u.h) is the Qur'an which still remains a challenge to this day as the Arabs have been unsuccessful in producing anything similar. Their inability to produce a single chapter similar to the Qur'an proves the validity and authenticity of the Qu'ran. It has been preserved for the last 14 centuries and it remains untainted and safe in the memory of millions of Muslims who have memorized it from the time of the Prophet (p.b.u.h) till today.

In addition, the acknowledgement of the existence of the spiritual world, according to Wajdi, would also indirectly open minds to the validity of the spiritual reality of prophethood. 
Discussion on spiritual reality existed far and wide among European intellectuals during the late 19th and early 20th centuries. For example, Wajdi highlights the establishment of the Society for Psychical Research (SPR) in 1882 in London. The SPR comprised mainly enthusiastic spiritualists, and attracted the attention of many eminent persons, such as, physicist and chemist, William Crookes, writer and physicist, Sir Oliver Lodge, philosopher, William James and psychologists, Sigmund Freud and Carl G. Jang (Wajdi, 1993). It was not only the members of the SPR who believed in spiritualism, but most people did, particularly the belief of the survival of the human soul after death. Although different schools of thought have different approaches to the survival of the soul and its states therein, all of them agree that the human soul is immortal and lives on after its separation from the body (Wajdi, 1993). This belief is due to intuitive feelings which indirectly stimulate man to search for the spiritual world. Wajdi reminds us that our comprehension of this worldly life is inadequate; hence, what more could be hoped for in terms of our knowledge for understanding the spiritual world? Therefore, it was the prophet (p.b.u.h) who revealed the realities of the spiritual world since he had direct contact with the spiritual world which is inaccessible to ordinary people (Wajdi, 1993). Although man in nature is always striving for worldly pursuits and bodily pleasures, he is at the same time a spiritual being. His spiritual needs could only be achieved through the teachings of the Prophet (p.b.u.h).

Last but not least, the validity of the Prophet (p.b.u.h) has also been proven through his great characteristics, attributes, attitude and manners, which he displayed throughout his lifetime. It is stated in one of his sayings, "I have only been sent to perfect good manners and attitude". The Prophet (p.b.u.h) never showed any blameworthy characteristics; only praiseworthy ones and this could be observed in his extensive biographies, all of which reflect his high and noble qualities. Even before his prophethood, the Prophet (p.b.u.h) was known in his community for his impeccable manners and attitude, such as, his honesty, truthfulness, trustworthiness and others although he lived in an ignorant society. Some people of the early period of Islam were influenced by the unquestionable character of the Prophet (p.b.u.h) and they accepted his prophethood on that basis (Al-Qasimi, 2003).

\subsection{THE ROLE OF THE PROPHET IN ESTABLISHING A CIVILIZED SOCIETY}

Wajdi is of the opinion that in order to understand the factors which determine the growth and development of the Muslim nation, one is required to study collectively two main issues, namely, the Qur'an and the Prophet (p.b.u.h). This is because the Qur'an shaped the Prophet (p.b.u.h) and the Prophet (p.b.u.h) shaped the Muslim world. Wajdi regards the Qur'an as the scheming mind and the Prophet (p.b.u.h) as the executive will (Majallah al-Azhar 14: 1). Applying the scientific approach, Wajdi notes the analogy between the building up of human groups and building up of living bodies. He wrote:

\footnotetext{
"In as much as any living body is built up of animate primary cells which possess characteristic qualities, behave collectively with strict conformity to the general system of that living, and cooperate in giving it generic and specific qualities, every buman group is built up of primary cells, which are the individuals forming that group, each having his own life, possessing characteristic qualities and obeying with others the disciplines governing and imparting unity to that group...In as much as the life of living bodies begins in a nucleus and spreads itself by forming cells which multiply until maturity is reached, every buman group forms around a nucleus, that is, one person destined to be its founder. When it reaches maturity, it begin to function" (Majallah al-Azhar 14: 1-2).
} 
Since Prophet Muhammad (p.b.u.h) is one of defining elements of Islam, it is important to observe the role of the Prophet (p.b.u.h). In his discussion on the role of the Prophet (p.b.u.h), Wajdi tries to reflect on the impact of the Prophet (p.b.u.h) on modernization. For Wajdi, true modernization requires the total vision of man to unify his material and spiritual aspects into a comprehensive system of life, and this is present in its most perfect form in the Prophet's teachings (Wajdi, 1967).

Prophet Muhammad (p.b.u.h), according to Wajdi, is the greatest human personality. He considers the Prophet (p.b.u.h) as a great reformist and leader in human history in terms of true civilization and culture. He expresses the greatness of the Prophet (p.b.u.h) as:

\begin{abstract}
"The Prophet possessed certain miracles that are beyond reason and science; neither intelligent people nor reformists can do it. He has weakened all the past and contemporary philosophers. He cannot be described as similar to other reformists, for all his great works cannot be done by others" (Wajdi, 1967 and Al-Jundi, Anwar, 1974).
\end{abstract}

As a reformist, the Prophet (p.b.u.h) has left a great spiritual legacy which has guided human civilization through the centuries. The legacy of the Prophet (p.b.u.h) has had such a great effect in the past and will have a greater effect in the future precisely because he has established the true religion and laid the foundation of the only civilization which guarantees the happiness of man. Therefore, the religion which the Prophet (p.b.u.h) conveyed and the civilization which he established at God's command are inseparable. In fact, according to Wajdi, the objective of religion is to build up a true civilization; he claims that a civilization only deserves to be called a true civilization if it can present Islam as a religion in its purest state (Wajdi, 1967). For Wajdi, Islam is a socio-civilizational religion which constitutes the needs of spiritual and material pursuits of life. At the same time, Wajdi highlights the difference between Islamic civilization and other civilizations. Islamic civilization is built upon the spiritual basis in which man is first and foremost called upon to recognize ultimate reality and to realize his position in the world with regards to that reality. The spiritual order constitutes the groundwork of all systems of life. In this regard, Wajdi regards Islam as a perfect model of civilization. He believes that everything the modern world has discovered and approved are mentioned in the Qur'an and hidden in its verses. For instance, the declaration of Human Rights by the West was first proposed by Islam 1,400 years ago. The sublime rank to which man has been elevated in the Qur'an is apparently far above his status in the declaration of Human Rights by the West (Wajdi, 1912).

Although the Qur'an does not mention directly about the political, legal, economic and social systems in governance, it presents many relevant principles, such as syura (mutual consultation), 'adalah (justice), musawah (equality), wasatiyyah (moderation), burriyyah (freedom), buquq (rights) and others. The Prophet (p.b.u.h) applied all principles enshrined in the Qur'an as a framework of an Islamic civilized society. For instance, the Prophet (p.b.u.h) was able to translate the Divine law into state law. The framework used by the Prophet (p.b.u.h) based on the principles enshrined in the Qur'an combined with his intellectual initiatives, has been proven to be efficient for harmonious social living. From the historical perspective, Prophet Muhammad (p.b.u.h) is the first prophet and leader who succeeded in putting into practice his policies in the political, legal, economic and social fields. Such implementation amply signifies the significant role of the Prophet (p.b.u.h) in establishing a civilized society in Islam.

Wajdi emphasizes that the Prophet (p.b.u.h) has brought a great change in the world's history. He was sent when the Arabs were in a state of ignorance. After the advent of the Prophet (p.b.u.h), the higher principles of social life were inculcated into Arabic society. Wajdi highlights both the ignorant state of the people of Arabia prior to the mission of the Prophet 
(p.b.u.h) and the state of the people under the light of revelation and prophethood (Majallah al_Azhar 5: 61). The Qur'an urges Muslims to avoid the former and follow the latter, and gives several comparisons between the two stages. In this regard, Wajdi quotes the following verse:

\begin{abstract}
"And judge, [O Muhammad], between them by what Allah has revealed and do not follow their inclinations and beware of them, lest they tempt you away from some of what Allah has revealed to you. And if they turn away - then know that Allah only intends to afflict them with some of their [own] sins. And indeed, many among the people are defiantly disobedient. Then is it the judgement of [the time of] ignorance they desire? But who is better than Allah in judgement for a people who are certain [in faith]" (Qur'an 5: 49-50).
\end{abstract}

Wajdi claims that there have been many revolutionary changes in the life and society of the Arabs, and the change brought by the prophet (p.b.u.h) is the greatest revolution. A revolution involves all aspects of life, including personal life and the family system. It also covers the military organization where the Prophet (p.b.u.h) himself was the commander-in-chief of the Muslim forces. In the educational system, the Prophet (p.b.u.h) was an advocate of the pursuit of knowledge and education although he himself was illiterate. The search for knowledge is enshrined in the Qur'an and propagated by the Prophet (p.b.u.h). Furthermore, the Prophet's revolution also focused on the economic system which was ignored in pre-Islamic Arabia. They never knew of a centralized government, and therefore, had no knowledge of public finance. The Prophet (p.b.u.h) was the first to set up a centralized state and an organized financial system. He was the first to initiate a public treasury in Madinah where he established five sources of state revenue systems, namely, zakah and sadaqah, jizyah, kharaj, khums of al-ghanimah and fay'. They became the five traditional taxes sanctioned by Islam. In addition, the Prophet (p.b.u.h) also elevated the status of women who were oppressed under the jabiliyyah system; they were granted due rights and privileges in issues related to family law.

The most important reform of the Prophet (p.b.u.h), according to Wajdi, is the unification of the Arab tribes into a single community based on allegiance to a single religion and a single political centre at Madinah (Wajdi, 1993). He built a new political organization called the ummah. The ummah built by the Prophet (p.b.u.h) is not based on kinship or blood relationship. It is not a temporary union for specific purposes and limited duration, but a permanent and indissoluble union based on the common allegiance to the Prophet (p.b.u.h) and loyalty to God. The state replaced the tribal system of pre-Islamic Arabia. Social injustice and inequalities were removed. Undoubtedly, it was a very difficult task to bring different people to universal brotherhood on the basis of one universal religion. It is at this point that Wajdi highly praises Prophet Muhammad (p.b.u.h) who established a universal brotherhood among the different tribes. The Arabs of the jabiliyyah period were proud of their lineage and forefathers. Each tribe claimed the greatest honour for itself. Therefore, for Wajdi, the success of the Prophet (p.b.u.h) in applying the principle of universal brotherhood is a great achievement which reformists of all generations strived for but were unable to achieve. Wajdi even notes the acknowledgement of some French philosophers of the greatness of the Prophet (p.b.u.h) (Majallab al-Az̧bar 4:2).

The unification of people from different tribes is a reflection of the universality of Islam. Wajdi refutes the claims of the Jewish and Christians on the universality of their religion. $\mathrm{He}$ mentions that Judaism built its universality on its claim as one unified human race that universally represents and dominates all mankind (Wajdi, 1993). As a chosen people, the people of Israel believe through their history to be standing in a unique relationship with God. They view the relationship between themselves and God as a covenant, and claim that they are the chosen ones to rule humanity as a whole based on the 10 commandments of God in the Torah. The claim of universality in Judaism, according to Wajdi, is invalid. However, he does not 
provide details of his denial since to him; there is an obvious aspect of exclusiveness in Judaism which contradicts the concept of universality in Islam (Wajdi, 1993). The Jewish law is meant for the Jews exclusively and is aimed at their perpetuation as a communal-racial group. Wajdi concludes that Jews in general falsely value themselves as a special community superior to any other human groups on earth. Wajdi also rejects the Christian claim on the universality of their religion. For them, the universality of Christianity is based on the concept of salvation. Salvation, the Christians believe, is founded upon the doctrine of vicarious atonement. Since human nature is considered to be sinful, as a consequence of the disobedience of Adam, Jesus took the responsibility to redeem the sins of mankind through his death and resurrection. In a nutshell, Jesus took man's place, and his death absolves all mankind's sins. To earn salvation, a Christian needs only faith in the death and resurrection of Jesus (Wajdi, 1993). After highlighting these beliefs in Christianity, Wajdi concludes that it could not be the universal religion of mankind for three main reasons. First, its beliefs could not be built on any proof or evidence, including rational proof. Thus, how could it be a universal religion that can be accepted by all of mankind if it is devoid of the most important principle of proof. Second, Christianity is built on the basis of asceticism and escapism from connections with worldly life, which is in contrast to the nature of societal life in general. Third, it abolishes the most important legal principle, that is, to oppose aggression forcibly. If the people are endowed with absolute forgiveness, there will be a constant degradation in the world. Thus, the concept of salvation in Christianity is an unsuitable kind of reform needed in society for the betterment of mankind (Wajdi, 1993).

In the foregoing analysis, Wajdi tries to convince mankind of the all-embracing role of the Prophet (p.b.u.h). He does not only focus on the spiritual role of the Prophet (p.b.u.h) but also stresses on his relationship to ummah to bring about a civilized Islamic state. He concurs with the views of al-Farabi who claims that the Prophet (p.b.u.h) did not only remain within the confines of his own personality but went forth to humanity, both with the divinely revealed religion and with a law based upon it. He was able to formulate his religious consciousness into a pattern of religious-political life for people to follow (Richard Waltzer, 1985). Wajdi argues that the Prophet (p.b.u.h) does not only possess a purely religious or mystic experience but he is also an active agent of social change who directed the forces of life and shaped the ends and purposes of individual and collective life. In this sense, Wajdi is opposed to the claim of the West that the Prophet's role was only confined to the individual spiritual life, thus disregarding the social, political and economic aspects. In this sense, the West has been battling for centuries to deny the role of the Prophet (p.b.u.h) as a founder of Islamic civilization. Wajdi emphasizes that the Prophet's role includes spiritual guidance as well as material guidance of man's life. His mission was not only to explain the principles of religion but also to establish a civilized model of society on the basis of Islam. Therefore, his role covers both individual and societal transformation.

Another point stressed by Wajdi is the significance of the finality of prophethood. For him, the Prophet (p.b.u.h) has left a great cultural legacy of Islam in terms of flourishing the spirit of rationality (Wajdi, 1993). After the death of the Prophet (p.b.u.h), a transition took place from blind dependence of men on Divine guidance to their dependence on their own intellect and freedom of action. This has been regarded as the culmination of the evolutionary process of human intellect. Therefore, Wajdi regards the spirit of the Prophet's revelation as the initiator of the modern world. This idea is similar to an Indian sub-continent philosopher, Muhammad Iqbal, who assumes the finality of the Prophet (p.b.u.h) as the birthplace of inductive intellect. In one statement about the Prophet (p.b.u.h), Iqbal wrote: 
"In so far as the source of his revelation is concerned, be belongs to the ancient world, in so far as the spirit of his revelation is concerned, be belongs to the modern world" (Iqbal, Mubammad, 1982).

Under the leadership of the Prophet (p.b.u.h) and the guidance from the Qur'an, the Muslim culture and civilization guarantee constant progress and betterment.

\subsection{CONCLUSION}

For the past two centuries, studies on Prophet Muhammad (p.b.u.h) have attracted the attention of the Western orientalists. They have published many studies which portray the negative views and misleading information about the Prophet (p.b.u.h) and until today, such misinterpretation has had an impact. We have witnessed the Judeo-Christian antagonism against the Prophet (p.b.u.h) and Islam in general. Therefore, it is necessary for Muslim scholars to refute the distorted information and misrepresentation of Prophet Muhammad (p.b.u.h). In this regard, Wajdi has made remarkable contributions by his logical way of discussion to refute the allegations propagated by the orientalists. This paper does not discuss the specific misrepresentation of the Prophet (p.b.u.h). However, it is adequate in that it provides relevant evidences and justifications. Wajdi's deliberation on the validity of prophethood is viewed as adequate to oppose the orientalists' rejection of prophethood on many grounds. In addition, Wajdi's arguments on the complete role of the Prophet (p.b.u.h) adequately and justifiably invalidate the orientalists' claim that Prophet Muhammad (p.b.u.h) was only a religious leader incapable of managing worldly affairs. In this regard, a detailed analysis on the role of the Prophet (p.b.u.h) in establishing a civilized society from different dimensions of governance is highlighted. Although many studies on Prophet Muhammad (p.b.u.h) have been conducted, they seem to be more descriptive rather than analytical, and it is at this juncture, that Wajdi fills the gap and applies logical arguments throughout the discussion. Due to his extensive writings on various aspects of Prophet Muhammad (p.b.u.h), particularly through his book, al-Sirah alMuhammadiyyah tahta dhau' al-'Ilm wa al-Falsafah, Wajdi can be considered as one of the prolific Muslim historiographers.

\section{Acknowledgement}

The author would like to express her gratitude for Research Management Centre, International Islamic University Malaysia (IIUM) for providing a research grant under RIGS.

\section{References}

Abdullah, Abdul Rahman. (1992). Pemikran Islam Masa Kini: Sejarah dan Aliran. Kuala Lumpur: Dewan Bahasa dan Pustaka.

Al-Faruqi, Ismail Raj. (1998). Islam and Other Faiths. Leicester: The Islamic Foundation and the International Institute of Islamic Thought.

Al-Faruqi, Ismail Raj. (1982). Tawbid: Its Implications for Thought and Life. Herndon: International Institute of Islamic Thought.

Al-Hajiri, Muhammad Taha. (1970). Mubammad Farid Wajdi: Hayatubu wa Atharubu. Cairo: Ma'ahad alBuhuth wa al-Dirasah al-'Arabiyyah wa al-Lughawiyyah.

Al-Jundi, Anwar. (1974). Muhammad Farid Wajdi: Ra'id al-Tawfiq bayn al-Tlm wa al-Din. Egypt: Al-Hay'ah Misriyyah al-'Ammah li al-Kitab.

Al-Qasimi, Muhammad Jamal al- Din. (2003). Mahasin al-Ta'wil. Beyrut: Dar al-Kutub al 'Ilmiyyah. 
Gibb, Hamilton Alexander Roskeen. (1947). Modern Trends in Islam. Chicago: University of Chicago Press.

Gibb, Hamilton Alexander Roskeen. (1953). Mohammedanism: An Historical Survey. London: Oxford University Press.

Goldziher, Ignz. (1981). Studies on Islam. Oxford: Oxford University Press.

Grunebaum, G.E. (1961). Islam: Essays in the Nature and Growth of a Cultural Tradition. London: Routlege and Kegan Paul LTD.

Iqbal, Muhammad. (1982). The Reconstruction of Religious Thought in Islam. Lahore: Shaikh Muhammad Asraf.

Majallah al Azhar 14:1

Majallah al_Azhar 14: 1-2

Majallah al-Azhar 5: 61

Majallah al-Azhar 4: 2

Rahman, Fazlur. (1958). Prophecy in Islam: Pbilosophy and Orthodoxy. London: The University of Chicago Press.

Rahman, Fazlur. (1978). "Divine Revelation and the Prophet". Hamdard Islamicus. Vol 1.no. 2: 66-72.

Richard Waltzer (trans). (1985). Al-Farabi on the Perfect State. Oxford: Clarendon Press.

Siddiqi, Mazheruddin. (1982). Modern Reformist Thought in the Muslim World. Islamabad: Islamic Research Institute.

Wajdi, Muhammad Farid. (1912). Al-Islam wa al-Madaniyyah. Cairo: Matba'ah al-Hindiyyah bi al-Munshi.

Wajdi, Muhammad Farid. (1967). Al-Islam fi 'Asr al-Ilm. Beyrut: Dar al-Kitab al-'Arabi.

Wajdi, Muhammad Farid. (1968). Al-Mushaf al-Mufassar. Cairo: Mua’assasah Dar al Sha’b.

Wajdi, Muhammad Farid. (1969). Tatbiq al-Diyanah al-Islamiyyah 'ala Nawamis al-Tabi'ah. Cairo: Maktabah al-Kulliyyah al-Azhayiyyah.

Wajdi, Muhammad Farid. (1993). Al-Sirah al-Muhammadiyyah tabta dhau' al-'Ilm wa al-Falsafah. Cairo: Dar al-Misriyyah al-Lubnaniyyah.

Wajdi, Muhammad Farid. (1997). Fusul min Sirat al-Rasul wa Mabahith Ukhra. Cairo: Al-Dar al-Misriyyah al-Lubnaniyyah. 